\title{
Mobile pocketbook of the 4 Cs skills-oriented inform of Quick Response Code
}

\author{
Bayu Rahmat Setiadi ${ }^{1}$, Subagyo ${ }^{2}$, Arif Bintoro Johan ${ }^{3}$, Muhammad Nurtanto ${ }^{4}$, Sugiyono ${ }^{5}$, \\ Heri Nurdiyanto ${ }^{6}$ \\ bayursetiadi@gmail.com ${ }^{1}$,yokssubagyo@gmail.com ${ }^{2}$, abeje_janoko@yahoo.com ${ }^{3}$, \\ mnurtanto23@untirta.ac.id ${ }^{4}$, sugiyono_1953@yahoo.com ${ }^{5}$, herinurdiyanto@gmail.com ${ }^{6}$ \\ ${ }^{123}$ Universitas Sarjanawiyata Tamansiswa, Yogyakarta, Indonesia, \\ ${ }^{4}$ Universitas Sultan Agung Tirtayasa, Serang, Indonesia \\ ${ }^{56}$ Universitas Negeri Yogyakarta, Yogyakarta, Indonesia
}

\begin{abstract}
Movement of paperless campus becomes a trend toward environmental sustainability, flexible learning, and 4Cs oriented (Creativity, Critical Thinking, Collaboration, and Communication). The use of 4Cs and Quick Response (QR) Codeoriented pocketbook is an alternative to building collaborative students 'reading culture and stimulating students' creativity, innovation, and thinking. The study uses three steps of activity that is planning, product, and evaluation. There are five experts involved in media validation including experts: media, information technology, materials, learning, and assessment of teaching. Tests conducted on 32 students of Mechanical Engineering Education Department of Universitas Sarjanawiyata Tamansiswa. The results showed that the dimensions of the pocketbook are A6 with a maximum thickness of $5 \mathrm{~mm}$, has a potent substance that is a chapter, learning objectives, material summary, QR Code equipped with the comprehensive material, and reference. Feasibility of media and information technology experts is $77.34 \%$ (very feasible). Eligibility of the content, learning, and evaluation of $66.44 \%$ (feasible) and the feasibility of the user is $75.11 \%$ (very feasible). In product, the QR Code-based mobile pocketbook is acceptable regarding appearance, content, substance, practicality, and efficiency in use.
\end{abstract}

Keywords: pocketbook, 4Cs, flexible learning, paperless campus, QR Code.

\section{Introduction}

The reading trends of the 21st century are now beginning to leave textbooks and start heading to electronic books (e-books). A person's interest in gadgets and the internet is part of the growing population of e-book readers in the world [1], [2]. Annie \& Duggan reported that the number of people reading e-books increased from 16\% for Americans aged 16 and to 23\% for those who were older [3]. At the same time, the number of those reading the printed book in 12 months fell to $72 \%$ of the population aged 16 , and the older fell to $67 \%$. This indicates an increase in enthusiastic people to read in electronic form and decreased interest in people to read in the printed version [4].

The existence of the e-book until now is the work of Project Guttenberg which released the first digital library since 1970 [5], [6]. E-book began to be famous all the people because it can be accessed free or paid either in the form of e-reader or file download. E-book makes the user more practical, efficient, efficient, and able to reduce the consumption of paper use [7]. 
Advances in information technology indicate a change in the basic needs of society to get all the information quickly, complete, and accurate from various sources.

The popularity of e-books in Indonesia is not as popular as in developed countries who are starting to leave printed books. Only $2 \%$ of Indonesians are using an official e-book registered with the Indonesian Publisher Association [8]. Until 2018, they have noted that 20\% of publishers are turning to e-book marketing which is expected to shift the paradigm of Indonesian people to switch in the electronic version. This opportunity should be well responded by the government to generate interest in reading children because the interest in reading Indonesian children is ranked 60th out of 61 sample research countries [9]. The contradictions of the findings from the Ministry of Communications and Information mention data that Indonesia ranked 6th in the world that access the internet and predicted in 2018 the number of netter reaches 123 million internet users [10]. Such contradictions should be a potential that should be exploited to arouse interest in reading books. Therefore, to stimulate interest in reading children, it is necessary to offer reading bids with electronic versions so that they can use their time practically by accessing the internet or downloading articles or e-books useful for science and knowledge [11]-[13].

Today, universities in Indonesia are beginning to prepare to shift the paradigm of paper usage to a minimum by replacing letters, information, documents, administration, teaching materials, and so on in soft files [14]. The paperless movement spread to all educational institutions in Indonesia [15]. Through the use of social media, all administration such as ebooks, invitations, and academic information is distributed rapidly. E-books that many students use consist of several kinds include e-handbook, e-module, e-job sheet, e-evaluation, and other electronic forms. The various e-books in the real way of paperless have not been able to provide behavior [16], and the students' reading interest proliferates considering that students tend to be dismissive when given an e-book and study it carefully [17]. These problems should be solved by providing a more communicative and interactive learning media that contains the summary and purpose of the lecture.

The habit of reading lecture material by Indonesian students outside of college hours, in general, is still far with other students outside Indonesia due to the interest of reading students outside of college hours is still low. Utilization technology is not used for reading the electronic material but for communicating and playing games. To remember students always to read the course material is to be summarized in the form of a pocketbook. The pocketbook is very practical for students to read in and spare their classes [18]. The pocketbook can be studied anywhere and anytime as it is very flexible to carry on learning [19]. A printed pocketbook cannot accommodate if the material provided for each meeting is so numerous. The thickness of the standard pocketbook is by the pocket size, in general, that is the equivalent of A6 paper. If it exceeds the size, then it cannot be tucked into a breast pocket. For that need to shrink the thickness of the book by combining the QR Code application.

QR Code applications are widely used by many countries, especially in education [20], [21]. QR Code can be scanned by various play store applications offered in the smartphone. A smart and multipage database can help a person to know the information stored in the barcode [22]. For that reason, QR Code needs to be optimally utilized in learning that accommodates large but small material in size and thickness.

Currently, 21st-century skills in the vocational world are increasingly emphasized by applying the 4Cs principles that include communication, collaboration, critical thinking, and creativity [23], [24]. The application of 4Cs to the demands that the university must fulfill [25] to emphasize the quality and quantity of materials and exercises that encourage cooperation among students, encourages the ability to think creatively, critically, and innovatively and can 
communicate the results of learning undertaken by students. This study is in line with the objectives of courses that emphasize $4 \mathrm{Cs}$ in all learning characteristics. The use of a practical mobile pocketbook with a combination of QR Code can be a student learning media in sharpening 4Cs skills. Both direct and indirect, the use of QR Code-based pocketbook can build motivation and interest of students to read and hone the ability of analysis based on materials developed in the QR Code. The use of pocketbook is considered appropriate to answer the solution of students in experiencing difficulties in learning as well as reading the latest information wherever and whenever that is documented in the form of a pocketbook. The existence of a minimalist print version gives the students do not forget the material presented and store the material documents at any time accessible to students[26].

\section{Research Methods}

The completion of QR Code-based mobile pocketbook needs in learning is designed concerning research and development steps designed by Richey \& Klein consisting of three main steps: planning, production, and evaluation [27]. The developed plan includes the components used in the development of a QR Code-based pocketbook. Also, planning also prepares of objective courses and teaching materials that are used. In this media trial using pneumatic and hydraulic courses. This media also inserts 21 st-century learning that includes creativity, critical thinking, communication, and collaboration[28].

Production process developed by making pocketbook. The designed Pocketbook includes learning objectives, material summaries, and QR Code as a comprehensive material description. To provide eligibility, improvements to the product made and compliance with product specifications, it is evaluated by conducting a feasibility test through expert judgment [29] media experts, information technology experts, teaching experts, materials experts, and evaluation experts. Experts selected based on their experience and expertise as references for pocketbook improvements. Also, the results of the next revision are tested to the user or student to know the practicality and ease in studying pneumatic and hydraulic courses.

This research was conducted at Universitas Sarjanawiyata Tamansiswa (UST) in Mechanical Engineering Education Department. Currently, UST is focusing on creating an environmental campus through a paperless movement. The purposive sample used is one class with 32 students. Pocketbook practicality test for students using a questionnaire with eight alternative answers. The questionnaire can measure the practicality and ease of users in using pocketbook and provide input in writing in the improvement of learning media. Data analysis techniques use descriptive statistics to measure mean, standard deviation, and percentage of the feasibility of pocketbook media based on this QR Code.

\section{Result and Discussions}

This study resulted in the feasibility of using pocketbook media of 4Cs-oriented and QR Code-based. The study offers a solution that the use of information technology assistance can support efforts in paperless movements [30]. In more depth, the results and discussion are outlined in three development steps including planning, production, and evaluation. 


\subsection{Planning of pocketbook based on QR Code}

Planning is an initial process that must be pursued to conform to product specifications [31]. Product specifications include:

- A6 or $105 \mathrm{~mm}$ x $148 \mathrm{~mm}$ pocketbook

- Maximum $5 \mathrm{~mm}$ book thickness

- Have a book cover that contains the vision, mission, goals, and objectives of the study program.

- Have a preface

- Have a table of contents

- The existence of materials and lecture objectives

- Material Summaries

- QR Code which contains comprehensive lecture material and evaluation

- QR Code applications in play store support in smartphone

The essence of this medium lies in the content of learning materials that refer to the $4 \mathrm{Cs}$ oriented learning. The material developed can accommodate the students in sharpening their creativity and critical thinking ability. By Bloom's pyramid, creativity is the highest level [32], and the material and competence measurements are inserted in the QR Code. Teaching materials designed to stimulate creative and critical thinking can provide a person's ability to create new mergers [33]. Creativity will depend significantly on one's creative thinking [34], i.e., the process of one's mind in creating new ideas. Therefore, in the material contained in the QR Code is more equipped with pictures and daily problems that can be solved by students through the creativity and innovation of thinking in solving the problems that exist in the material. Images can be illustrative for the reader to make it easier to understand the material delivered than many texts [35], [36]. The resulting impact of digital literacy on smartphones will give students the ability to communicate and collaborate with peers to solve problems creatively and critically. By forming class discussions freely, students can exchange information with their friends to gain new knowledge[37].

\subsection{Product}

Prepared planning is continued by developing QR Code-based pocketbook products. Results from the development of pocketbook products as follows. 


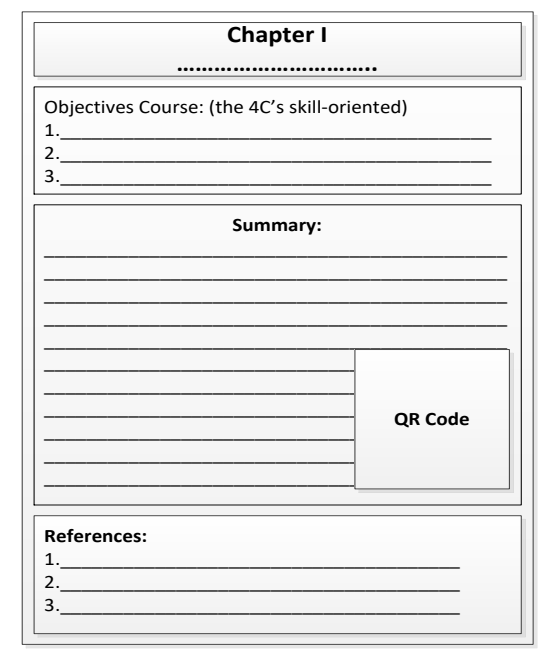

Fig. 1. The substance of pocketbook based on QR Code

The material contained in QR Code is filled with integrating 21st-century skills in the form of 4 Cs. If the scanner is brought closer to the QR Code, it will be connected to the learning material [38]. In the e-book is contained the completeness of the design of the implementation of learning, the material is taught entirely with images that can stimulate the creativity and innovation of students in critical thinking, material summary, learning evaluation, and reference of each learning material. The product results in Fig. 1 is a manifestation of expert validation both regarding appearance, substance, layout, and communicative information submitted to the reader to have a simple but implied impression of the meaning of broad and comprehensive learning.

\subsection{Evaluation of product}

Product evaluation is used to find out how far the developed product is feasible and practical to use [39], [40]. Evaluation referred to the instrument compiled and distributed to the expert and tested on the user. Evaluation results will be an improvement and development in the pocketbook to be readily accepted by students. The following is a validation result from some experts who assess this media.

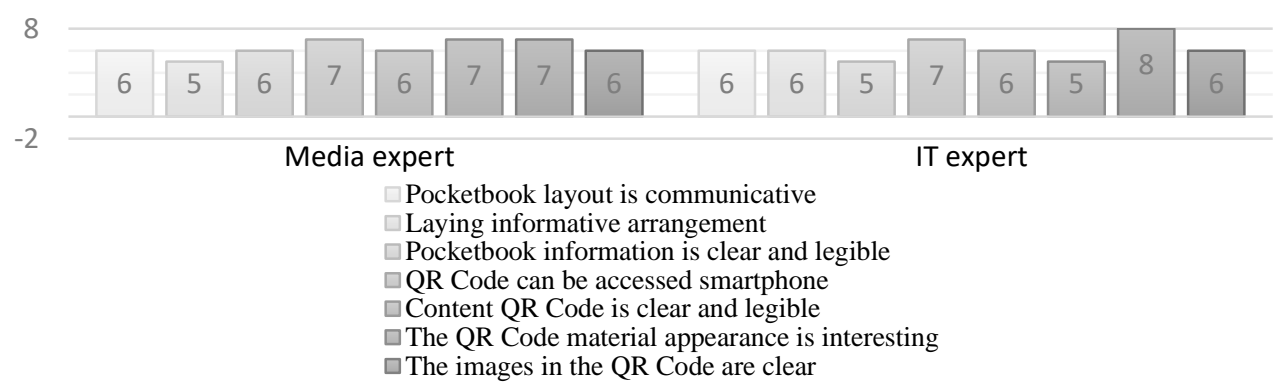

Fig. 2. Pocketbook assessment based on QR Code by media experts 
Based on the assessment of both media experts found that the total value generated is 99 . This means the percentage produced is $77.34 \%$ of 128 maximum scores. If it refers to four feasibility intervals $(0-24,5 \%=$ unworthy; $25 \%-49,5 \%=$ enough; $50 \%-74,5 \%=$ feasible; and $75 \%-100 \%=$ very feasible) then the score including in a very feasible category. This means the agreement between the two media experts stated that the media used could be received either in appearance, layout, graphics, information, and access speed. Although the results are good, some of the inputs provided by media experts include: (1) the use of multiple graphics precisely gives the appearance of the appearance of being unfocused on the material; (2) putting the QR Code inherent with the material summary; (3) need to be equipped with links or doi for reference so that readers can access the reference of teaching materials in an integrated manner; and (4) pocketbooks do not need to be thick and bulky but can be tucked into standard pocket sizes.

The first improvement was made as input to media experts. Material experts further validate the revised fixes. This is done because the material developed also needs to be evaluated to be accepted and understood by the multi-characteristic students [41]. There are three material experts used, i.e., learning experts, pneumatic and hydraulic experts, and teaching evaluation experts. The following is a tabulation of the material expert's judgment data.

Table 1. Review of material experts on the feasibility of pocketbook

\begin{tabular}{|c|c|c|c|c|}
\hline & Didactic Requirement & $\begin{array}{c}\text { Learning } \\
\text { Expert }\end{array}$ & $\begin{array}{c}\text { Subject } \\
\text { expert }\end{array}$ & $\begin{array}{c}\text { Evaluation } \\
\text { expert }\end{array}$ \\
\hline \multicolumn{5}{|c|}{ Review pocketbook (Scale of 1-8) } \\
\hline 1. & $\begin{array}{l}\text { The course and information of each chapter are clearly } \\
\text { stated. }\end{array}$ & 6 & 5 & 5 \\
\hline 2. & $\begin{array}{l}\text { The purpose of the course is based on the } 4 \text { Cs skills } \\
\text { approach. }\end{array}$ & 5 & 5 & 6 \\
\hline 3. & $\begin{array}{l}\text { Summary of material is briefly described, bright, and } \\
\text { easy to understand. }\end{array}$ & 5 & 4 & 4 \\
\hline 4. & $\begin{array}{l}\text { Summary material stimulates the reader to think } \\
\text { creatively and critically. }\end{array}$ & 5 & 5 & 5 \\
\hline 5. & $\begin{array}{l}\text { References used up to date (maximum of the last five } \\
\text { years). }\end{array}$ & 5 & 4 & 5 \\
\hline \multicolumn{5}{|c|}{ Material review in the form of QR Code (Scale of 1-8) } \\
\hline & $\begin{array}{l}\text { There are goals and indicators or achievements of } \\
\text { learning-oriented to } 4 \mathrm{Cs} \text {. }\end{array}$ & 5 & 5 & 5 \\
\hline 7. & Material developed based on concept maps. & 6 & 6 & 6 \\
\hline 8. & The material drawn up refers to the skills of 4 Cs. & 5 & 5 & 6 \\
\hline 9. & An inductive approach prepares the material. & 7 & 5 & 5 \\
\hline 10. & $\begin{array}{l}\text { Images and visual information (tables and graphs) are } \\
\text { relevant to the material being taught. }\end{array}$ & 7 & 6 & 6 \\
\hline 11. & $\begin{array}{l}\text { The material can hone the creativity and innovation of } \\
\text { student thinking. }\end{array}$ & 4 & 5 & 5 \\
\hline 12. & Materials can stimulate students to collaborate. & 4 & 4 & 5 \\
\hline 13. & $\begin{array}{l}\text { There are tasks or exercise questions that can measure } \\
\text { students' } 4 \text { Cs skills. }\end{array}$ & 5 & 5 & 4 \\
\hline 14. & $\begin{array}{l}\text { Tasks or exercises developed to improve the power of } \\
\text { student analysis. }\end{array}$ & 6 & 5 & 5 \\
\hline 15. & References used up-to-date & 6 & 4 & 6 \\
\hline Total & & 81 & 73 & 78 \\
\hline
\end{tabular}


Based on Table 1 shows that the total score of the three material experts is 232 with the assumption that the maximum value is 360 . If calculated by presentation then get the value of presentation $64.44 \%$. Referring to the feasibility category meaning interval then according to developed material experts fall into the category worthy. This feasibility is considered to provide opportunities for readers to explore the material with independent and flexible [42]. Some of the inputs provided by the three material experts are: (1) Learning objectives and indicators are more specific and contain evident 4Cs skills; (2) A better-made summary of material highlights favorite issues and stimulates students' sense of knowing more in-depth the material stored in the QR Code; (3) The material in the QR Code is reproduced with relevant drawings or illustrations in stimulating a more straightforward and more easily understood mindset of the student; (4) Problems arranged are varied and include how to hone the skills of 4Cs students. The results of the input of experts are then revised and continued to the evaluation phase of users.

The revision of the media produced by expert judgments was then deployed to the students of the Department of Mechanical Engineering of UST. Students providing a feasibility assessment through the questionnaire provided with the assessment substance are pocketbook display, pocketbook content and QR Code, 4Cs integrated materials, practicality, and usability efficiency. The following is the result of a questionnaire of 32 students of pneumatic and hydraulic classes.

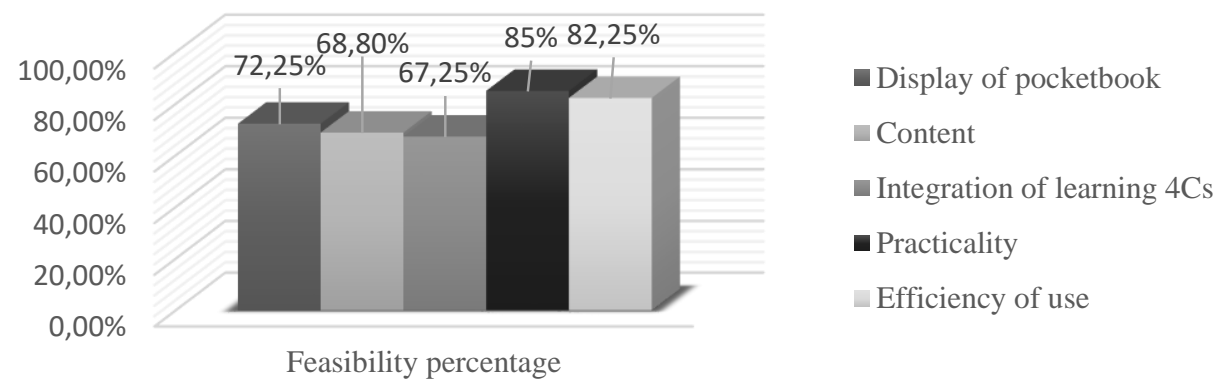

Fig. 3. User feasibility assessment

Based on the user's feasibility histogram, it was found that $75.11 \%$ of students concluded that QR Code-based pocketbook media were in the very reasonable category according to the four feasible criteria. Although there are still unsatisfactory conditions, of the five overall assessment criteria are in reasonable condition. Referring to the result can be concluded that pocketbook media based on QR Code can be accepted by the user and can be accessed flexibly and practically.

The results of reviews by experts and users provide information about the advancement of educational technology that the use of mobile pocketbook can be used in flexible learning and can stimulate interest in reading students. Paperless movements should be sought from an early age so that advanced education can become a sustainable lifestyle [43], [44]. Encouraging students and lecturers to use QR Code-based pocketbooks can reduce excessive paper consumption in lectures by learning to use mobile phones [42]. With the 4Cs approach in the material contained in QR Code able to give the students to be creative and innovative in thinking and solving problems with the comprehensive and appropriate analysis. 


\section{Conclusions}

This research concludes that mobile media pocketbook based on QR Code and integrated 4Cs are arranged through three stages: planning, product, and evaluation. Pocketbook dimensions are equivalent to A6 size with a maximum thickness of $5 \mathrm{~mm}$. Book view includes a cover, introduction, table of contents, material chapter, learning objectives, material summaries, QR Code (comprehensive material), and references. Screening QR Code using the existing play store app on the smartphone. The results of the assessment by media and IT experts stated that it is feasible with a percentage of $77.34 \%$ based on viewing judgment, access speed, informative functions, written and image clarity, and QR Code functionality. The result of a revision of media expert is validated by material expert, learning expert, and education evaluation expert with $64.44 \%$ percentage or eligible category with criteria of lecturing completeness assessment, material suitability with 4Cs skills-oriented, clarity of writing and drawing, which stimulates the ability to think critically and the creativity of the students. Also, the media is also tested in limited classes with $75.11 \%$ results or in eligible categories based on content, content, $4 \mathrm{Cs}$ content criteria, practicality, and usability criteria. The acceptance of the QR Code-based pocketbook recommends vocational lecturers to use the media as a step in realizing the paperless campus movement.

\section{References}

[1] S. Marques de Oliveira, "E-textbooks usage by students at Andrews University," Libr. Manag., vol. 33, no. 8/9, pp. 536-560, 2012.

[2] N. M. Foasberg, "Adoption of E-Book Readers Among College Students: A Survey,” Inf. Technol. Libr., vol. 30, no. 3, pp. 108-128, 2011.

[3] L. Rainie and M. Duggan, "E-book reading jumps; print book reading declines," PewInternet, no. November 2012, p. 15, 2012.

[4] L. Rainie, K. Zickuhr, K. Purcell, M. Madden, and J. Brenner, "The rise of e-reading," Washington, D.C, 2012.

[5] M. Lebert, "A Short History of eBooks," Gutenb. Proj., vol. 010101, pp. 1-87, 2009.

[6] D. Waller, "Current Advantages and Disadvantages of Using E-Textbooks in Texas Higher Education.," Focus Coll. Univ. Sch., vol. 7, no. 1, pp. 1-6, 2013.

[7] C. Chao, N. Hegarty, and S. Abraham, "Global Impacts and Challenges of Paperless Books : A Preliminary Study,” Int. J. Bus. Soc. Sci., vol. 3, no. 11, pp. 115-122, 2012.

[8] IKAPI, "Data Perbukuan Indonesia," IKAPI, 2018. .

[9] Miller and M. C. McKenna, "World Literacy: How Countries Rank And Why It Matters,” 2016.

[10] eMarketer, "2 Billion Consumers Worldwide to Get Smart ( phones ) by 2016 Over half of mobile phone users globally will have smartphones in 2018," 2014.

[11] J. W. Warren, "Innovation and the future of e-books," Int. J. B., vol. 6, no. 1, pp. 159-166, 2011.

[12] H. Jeong, "A comparison of the influence of electronic books and paper books on reading comprehension, eye fatigue, and perception," Electron. Libr., vol. 30, no. 3, pp. 390-408, 2012.

[13] M. N. Byars, "Printed Books versus Digital Books," San Luis Obispo, 2015.

[14] M. Sulistiyono and F. Yasin, "Pemanfaatan Paperless Office System Dalam E- Government Studi Kasus Kementrian Pendidikan Dan,” J. Teknol. Inf., vol. XI, no. 31, pp. 18-26, 2016.

[15] N. K. S. Putri, Hudiarto, Argogalih, and H. Muljoredjo, "The use of green information technology governance model to determine capability maturity level in dki jakarta private higher education institutions," J. Theor. Appl. Inf. Technol., vol. 61, no. 1, 2014.

[16] B. Sopha, "Sustainable Paper Consumption: Exploring Behavioral Factors," Soc. Sci., vol. 2, no. 
4, pp. 270-283, 2013.

[17] C. Cowan, "PRINTED BOOKS VERSUS E-BOOK FORMATS: A STUDY USING NICHE GRATIFICATION THEORY by," The University of Alabama, 2013.

[18] A. B. N. R. Putra, W. Irdianto, A. Mukhadis, and S. Suhartadi, "Pocket book learning: Learning methods to train students productive and creative using 'BRANO' as an effective learning recorder," AIP Conf. Proc., vol. 1778, 2016.

[19] L. Sofiana and S. M. Ayu, "Pocket Book to Enhance Knowledge and Attitude Regarding Prevention of Soil-Transmitted Helminth," Int. J. Eval. Res. Educ., vol. 6, no. 3, pp. 252-256, 2017.

[20] C. Law and S. So, "QR Codes in Education," J. Educ. Technol. Dev. Exch., vol. 3, no. 1, 2010

[21] E. E. Ozkeskin, "QR Codes in education and communication," Turkish Online J. Distance Educ., vol. 17, no. April, pp. 42-58, 2016.

[22] X. Wei, A. Manori, N. Devnath, N. Pasi, and V. Kumar, "QR Code Based Smart Attendance System," Int. J. Smart Bus. Technol., vol. 5, no. 1, pp. 1-10, 2017.

[23] J. Schatz, "From the Cabinet 21 st Century Skills , continued," 2015.

[24] E. M. Reeve, "21st century skills needed by students in technical and vocational education and training (TVET)," Asian Int. J. Soc. Sci., vol. 16, no. 4, pp. 62-74, 2016.

[25] R. Harshbarger, "Learning in the 21st Century: A Study Addressing Educational Trends and Implications," the University of Central Florida, 2016.

[26] H. Nurdiyanto, "A work-based learning model with technopreneurship," Glob. J. Eng. Educ., vol. 20, no. 1, pp. 75-78, 2018.

[27] R. C. Richey and J. D. Klein, "Developmental research methods: Creating knowledge from instructional design and development practice," J. Comput. High. Educ., vol. 16, no. 2, pp. 23 38, 2005.

[28] H. Nurdiyanto, R. Rahim, S. Nurarif, and M. Ramadhan, "Enhanced pixel value differencing steganography with government standard algorithm," in Proceeding - 2017 rrd International Conference on Science in Information Technology: Theory and Application of IT for Education, Industry and Society in Big Data Era, ICSITech 2017, 2018, vol. 2018-Janua.

[29] S. Hora and M. Jensen, "Expert Judgement Elicitation," 2007.

[30] A. R. Khakim, "Implementasi Paperless di Era Informasi : Langkah Cerdas Peduli Lingkungan," 2014.

[31] R. Hummelbrunner and H. Jones, "A guide for planning and strategy development in the face of complexity," London, 2013.

[32] M. Forehand, "BloomsTaxonomy.pdf," Bloom's Taxanomy-Emerging Perspective on Learning, Teaching and Technology. p. 10, 2011.

[33] S. A. Rahman and N. F. A. Manaf, "A Critical Analysis of Bloom's Taxonomy in Teaching Creative and Critical Thinking Skills in Malaysia through English Literature," English Lang. Teach., vol. 10, no. 9, p. 245, 2017.

[34] Č. Vesna and M. Mulej, "Creative Thinking and Decision-Making Analysis - Requisite Factors of Innovation Capacity," vol. 2002, no. May. 2004.

[35] Z. Fang, "Reading Horizons Illustrations, Text, and the Child Reader : What are Pictures in Children 's Storybooks for? Illustrations, Text, and the Child Reader: What are Pictures in Children 's Storybooks for?," Read. Horizons, vol. 37, no. 2, pp. 130-142, 1996.

[36] A. Hatva, "What impact does an illustrated article have ?," 2005.

[37] D. Napitupulu et al., "Analysis of Student Satisfaction Toward Quality of Service Facility," in Journal of Physics: Conference Series, 2018, vol. 954, no. 1.

[38] F. Masalha and N. Hirzallah, "A Students Attendance System Using QR Code," Int. J. Adv. Comput. Sci. Appl., vol. 5, no. 3, pp. 75-79, 2014.

[39] R. C. Richey, J. D. Klein, and W. a Nelson, "Developmental Research : Studies of Instructional Design and Development," Development, vol. 2, no. April 2002, pp. 1099-1130, 2004.

[40] K. Bause, A. Radimersky, M. Iwanicki, and A. Albers, "Feasibility studies in the product development process," Procedia CIRP, vol. 21, pp. 473-478, 2014.

[41] R. M. Felder and R. Brent, "Understanding student differences," J. Eng. Educ., vol. 94, no. 1, 
pp. 57-72, 2005.

[42] J. Casey and P. Wilson, A practical guide to providing flexible learning in further and higher education. Scotland: the Quality Assurance Agency for Higher Education (QAA), 2005.

[43] N. Murthy, "Paperless organization," Asia Pacific J. Mark. Manag. Rev., vol. 2, no. 9, pp. 8797, 2013.

[44] M. Hafiz Iqbal and F. Ahmed, "Paperless Campus: The Real Contribution towards a Sustainable Low Carbon Society,” IOSR J. Environ. Sci. Ver. I, vol. 9, no. August 2015, pp. 2319-2399, 2015. 